\title{
Discussion: Advice, methods and tools for estimating channel roughness
}

Caroline McGahey MSc, PhD

Principal Engineer, Floods Group, HR Wallingford Ltd, Wallingford, UK Donald Knight MSC, PhD, CEng, MICE, MCIWEM, MASCE

Emeritus Professor of Water Engineering, The University of Birmingham, UK
Paul Samuels MA, PhD, CEng, CMath, FIMA, MICE, MCIWEM Techinical Director, Floods Group, HR Wallingford Ltd, Wallingford, UK Charles R. Neill MSC, PEng, MICE

Principal Engineer, Northwest Hydraulic Consultants, Edmonton, Canada

\section{Contribution by Charles Neill}

Perusal of the paper by McGahey et al. (2009) suggests that the Environment Agency's 'roughness advisor' on which it is based does not give much attention to the wide variations of roughness that can occur in alluvial streams as a result of changing bedform configurations and high sediment concentrations.

As perhaps an extreme example, the Padma River in central Bangladesh combines the flows of the Jamuna (Brahmaputra) and the Ganges and is one of the largest rivers in the world. It has an average width of about $5 \mathrm{~km}$, maximum depths of about $50 \mathrm{~m}$ and a gradient of about $5 \mathrm{~cm} / \mathrm{km}$. Its bed consists of very fine sand with a median grain size of about $0 \cdot 12 \mathrm{~mm}$. Recent hydraulic analyses in connection with a proposed bridge crossing have produced a roughness-discharge curve more or less parallel to one previously published for the river by Simons and Senturk (1977), showing that Manning's $n$ decreases from about 0.040 at low flow $\left(5000 \mathrm{~m}^{3} / \mathrm{s}\right)$ to about 0.012 at bankfull flow $\left(75000 \mathrm{~m}^{3} / \mathrm{s}\right)$. This dramatic reduction in roughness with discharge is probably largely associated with observed flattening and washing out of dune-type bedforms, but may also be influenced by increasingly heavy concentrations of suspended sediment near the bed that dampen turbulent exchange.

The Simons and Senturk (1977) relationship was based on a consultants report from 1970. Similar results for the Jamuna (Brahmaputra) River, expressed in terms of Chezy's $C$, were reported by Islam and Chowdhury (2003).

While truly alluvial streams may represent a small percentage of the whole in the UK, in other regions they may predominate. Users of the roughness advisor should be aware of this apparent limitation.

\section{Authors' reply}

The authors thank Dr Neill for highlighting the important limitation of the conveyance estimation system (CES) in that it does not take account of changes in hydraulic roughness resulting from changes in alluvial bedforms, as covered in the detailed documentation of the software (Defra/EA, 2003; McGahey, 2006).

The design of the roughness advisor and the CES conveyance calculation was focused on use in UK channels as it was funded by UK organisations. Typical channels in the UK are small compared with major international rivers and few have largescale bedforms that change significantly with discharge. The conditions in the Padma River, referred to by Dr Neill, are very different from those observed in typical UK channels. The alluvial conditions in the large rivers in Bangladesh are well known to the authors from their work in the early 1990s on the flood action plan, which revealed similar variation in resistance to those quoted by Dr Neill. Similar conditions have also been observed in the Indus River in Pakistan (Ackers et al., 1988), where large changes in water depth have been observed for the same discharge due to large changes in roughness. The CES may be used for alluvial channels as an exploratory tool, by adopting different static roughness values for different discharges. Alternatively, there are a number of alluvial friction theories that can be used (outside the CES) and the resulting predicted roughness values inserted in the CES.

During testing, the CES was applied to the River Alto Parana in Argentina, a substantial alluvial river $\left(>20000 \mathrm{~m}^{3} / \mathrm{s}\right)$, adopting a single static roughness for all discharges. It was found that the methods were unable to reproduce the observed flows and levels. This was attributed to

(a) the very large channel size

(b) no explicit representation of the growth and decay of the alluvial roughness features

(c) possible unknown flow processes (McGahey, 2006).

Quoting from Section 5.1.5 of McGahey (2006)

The River Alto Parana is considerable, with measured flow rates of up to $25000 \mathrm{~m}^{3} \mathrm{~s}^{-1}$. [Figure 12] shows the surveyed geometry at the El Dorado measurement site. The CES is unable to simulate the observed stage-discharge relationship [Figure 13], regardless of the adopted static roughness value or water surface slope. The discharge is over-predicted at low depths and under-predicted at large depths. This behaviour is not unusual in that the river is characterised by alluvial roughness and 'sand bars', and thus at low flows, there is likely to be increased resistance due to the presence of bedforms whereas at high flows, these bedforms are washed away, reducing the overall bed resistance and increasing flow capacity. This has 


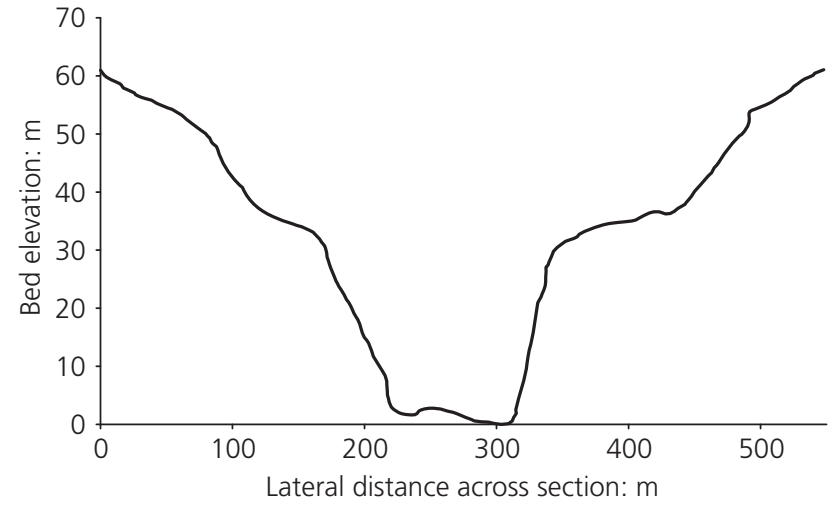

Figure 12. Surveyed cross-section geometry for the River Alto Parana, El Dorado, Argentina (McGahey, 2006)

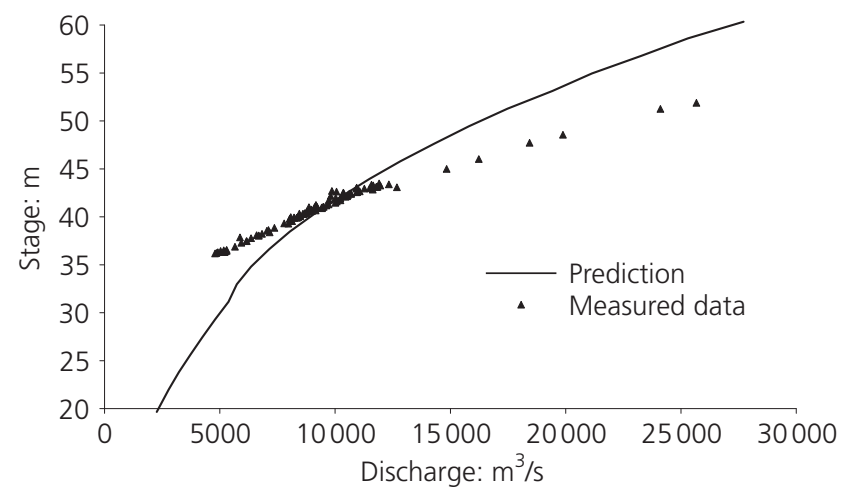

Figure 13. CES stage-discharge prediction and data for the River Alto Parana, El Dorado, Argentina (McGahey, 2006)

previously been observed in very large rivers such as the Brahmaputra River (Hossain et al., 1987), where in some instances the same water level satisfies two entirely different resistance regimes. The poor simulations may be exacerbated by the use of the Colebrook-White Law, which may be inappropriate for simulating the variation of roughness with depth in this scale of river, regardless of the alluvial nature, or to changes in the typically observed flow processes, which only occur at such large scales. The 'calibrated' or 'adopted' static roughness value is 0.090 , which is high and corresponds to a $k_{\mathrm{s}}$ value of $3 \mathrm{~m}$, possibly indicating the presence of bedforms.

An important recommendation from the CES development was to extend the software in future to incorporate different alluvial friction theories.

\section{REFERENCES}

Ackers P, Hogg IGG, Guganesharajah K and Gunn PDS (1988) The influence of river regime on the flood management of Sukkur Barrage, Pakistan. Proceedings of an International Conference on River Regime (White WR (ed.)). Wiley, Wallingford, UK.

Defra/EA (Department for Environment, Food and Rural Affairs/ Environment Agency) (2003) Reducing Uncertainty in River Flood Conveyance: Interim Report 3 Review of Methods for Estimating Conveyance. HR Wallingford, Wallingford, UK, Project W5A-057.

Hossain M, Islam ATM and Saha SK (1987) Floods in Bangladesh: Recurrent Disaster and People's Survival. Universities Research Centre, Dhaka, Bangladesh.

Islam GMT and Chowdhury JU (2003) Hydraulic characteristics of the Jamuna River gauging section, Bangladesh.

Proceedings of the Institution of Civil Engineers - Water and Maritime Engineering 156(3): 219-224.

McGahey C (2006) A Practical Approach to Estimating the Flow Capacity of Rivers. $\mathrm{PhD}$ thesis, Open University, Milton Keynes, UK.

McGahey C, Knight D and Samuels P (2009) Advice, methods and tools for estimating channel roughness. Proceedings of the Institution of Civil Engineers - Water Management 162(6): 353-362.

Simons DB and Senturk F (1977) Sediment Transport Technology. Water Resources Publications, Highlands Ranch, CO, USA.

\section{WHAT DO YOU THINK?}

To discuss this paper, please email up to 500 words to the editor at journals@ice.org.uk. Your contribution will be forwarded to the author(s) for a reply and, if considered appropriate by the editorial panel, will be published as a discussion in a future issue of the journal.

Proceedings journals rely entirely on contributions sent in by civil engineering professionals, academics and students. Papers should be 2000-5000 words long (briefing papers should be 1000-2000 words long), with adequate illustrations and references. You can submit your paper online via www.icevirtuallibrary.com/content/journals, where you will also find detailed author guidelines. 